\title{
PERAN PEREMPUAN PADA SEKTOR JASA PELAYANAN PERPUSTAKAAN DI PERPUSTAKAAN UNIVERSITAS GADJAH MADA YOGYAKARTA
}

\author{
Oleh: Yuli Hesti Wahyuningsih* dan Tafrikhuddin**
}

\begin{abstract}
INTISARI
Perpustakaan merupakan komponen penunjang yang penting dalam proses pendidikan tinggi. Salah satu aspek yang sangat berperan terhadap pelayanan perpustakaan adalah aspek SDM baik secara kualitas maupun kuantitas. Perempuan merupakan bagian dari SDM yang patut diperhitungkan mengingat kesempatan mereka untuk berperan terhadap berbagai bidang semakin luas termasuk peran dalam bidang pelayanan perpustakaan. Perpustakaan UGM secara kuantitas memiliki pegawai perempuan yang cukup besar. Permasalahannya, belum diketahui bagaimana peran mereka pada sektor jasa pelayanan perpustakaan. Penelitian ini bertujuan untuk menjawab permasalahan tersebut, dan diharapkan bermanfaat untuk memberikan sumbangan pemikiran pada sektor jasa pelayanan perpustakaan, terutama peningkatan peran perempuan pada sektor jasa pelayanan perpustakaan yang profesional. Permasalahan tersebut dikupas dengan mempergunakan metoda kualitatif. Teknik pengumpulan data dilakukan melalui observasi, wawancara mendalam, dan dokumentasi. Selanjutnya data dianalisis dan diolah melalui tahap reduksi data, penyajian data, analisis data, dan penarikan kesimpulan. Dari hásil penelitian ini diketahui bahwa peran perempuan dalam jasa pelayanan perpustakaan antara lain dipengaruhi oleh beberapa hal, yaitu tanggapan perempuan yang terdiri dari persepsi dan motivasi, serta sikap; partisipasi; dan kompetensi. Sejauh ini peran perempuan lebih dominan pada bidang pelayanan yang langsung berhadapan dengan pengguna berkaitan dengan sifat perempuan yang ramah, terampil, dan rajin. Perpustakaan UGM memberikan peluang yang sama bagi perempuan untuk memberikan peranannya.
\end{abstract}

Kata Kunci : Peran Perempuan, Motivasi, Partisipasi, Kompetensi.

\section{ABSTRACT}

Library has been a vital component within higher education system. Within library itself, human resource plays a significant role, both quantitatively and qualitatively. Women's role, as a part of human resource, has been getting more significant due to the extension of women's opportunities to take part in various areas previously closed for them, including in library service. Within the Library of Gadjah Mada University, the number of female librarian outnumbers the male one. The question is, "How significant is the role of these women employers to the service's performance in the Library of Gadjah Mada University?" This research was intended to answer the question above. Next, it was expected that the result of this research will contribute some notions for the development of library service, especially in enhancing the professional role and performance of female librarians. This research would be conducted through qualitative methods. In gathering the needed data, it use observation, interview, and documentation methods. The data collected would be analysed through a set of steps including data reduction, data presentation, data analysis, and concluding process. this research would reveal that the role and performance of female librarians within the library service at Gadjah Mada University is determined by various factors. They were: women's respond to perception and motivation, attitude, participation, and competence. So far, women's role tends to be concentrated in customer service area, based on the assumption of their passionate, hospitable, and careful natures. The University policies have been giving wider opportunities for female librarians to take greater role.

* Pustakawan UGM

*** Fak.ADAB UIN Sunan Kalijaga Yogyakarta

\section{PENDAHULUAN}

Pendidikan merupakan salah satu upaya untuk mencerdaskan kehidupan bangsa dan menjadi pilar utama dalam pembangunan SDM yang berkualitas. Hal itu tercantum dalam pasal 31 UUD 1945. Sebagai implementasinya maka pemerintah mengeluarkan UU No. 20 Tahun 2003 tentang Sistem Pendidikan Nasional. Dalam pasal 45 ayat (1) dinyatakan "setiap satuan pendidikan formal dan nonformal menyediakan sarana dan prasarana yang memenuhi keperluan pendidikan sesuai dengan pertumbuhan dan 
perkembangan potensi fisik, kecerdasan intelektual, sosial, emosional, dan kejiwaan peserta didik." Salah satu sarana pendidikan tersebut adalah perpustakaan.

Universitas Gadjah Mada (UGM) sebagai salah satu bagian dari sistem pendidikan tinggi juga menyediakan prasarana perpustakaan untuk menunjang kelancaran kegiatan belajar. Perpustakaan UGM berkedudukan di bawah, bertanggungjawab, dan dibina oleh pimpinan universitas. Secara umum fungsi perpustakaan UGM adalah memberikan layanan pendidikan, penelitian, pengabdian kepada masyarakat, merencanakan dan melaksanakan kegiatan sesuai dengan bidangnya, dan melaporkan secara periodik kepada pimpinan universitas. Perpustakaan merupakan "jantung" dari sebuah universitas, sehingga perpustakaan merupakan organ penting dalam proses pendidikan, pembelajaran, penelitian, dan pengabdian kepada masyarakat. Kualitas suatu perguruan tinggi dapat dilihat dari kualitas perpustakaannya. Sebagai unsur penunjang penyelenggaraan pendidikan dan penyebaran informasi, perpustakaan diharapkan mampu melayani masyarakat pengguna dengan baik dan profesional.

Salah satu aspek yang cukup strategis bagi perpustakaan dalam melayani masyarakat penggunanya adalah aspek SDM baik secara kualitas maupun kuantitas, termasuk dalam hal ini adalah SDM perempuan. Keberadaan perempuan pada sektor jasa pelayanan perpustakaan merupakan fenomena menarik yang memerlukan kajian lebih mendalam.

Dari sisi kuantitas, penduduk perempuan lebih dari setengah penduduk Indonesia. Secara ideal perempuan memiliki akses yang sama dengan laki-laki di berbagai bidang kehidupan baik kehidupan sosial, budaya, ekonomi, maupun politik. Namun demikian idealisme ini belum pernah menjadi kenyataan karena pada beberapa bidang kehidupan belum memperoleh akses yang sama dengan laki-laki. pada dasarnya pengakuan tentang kesamaan hak bagi perempuan dan lakilaki telah diadopsi oleh Pemerintah Indonesia. Salah satu butir dalm GBHN 1993 mengamanatkan bahwa perempuan sebagai potensi manusia pembangunan harus diberi hak dan kewajiban serta kesempatan yang sama dengan laki-laki dalam pembangunan di segala bidang. Di lain pihak, dengan semakin luasnya kesempatan bagi perempuan untuk menuntut ilmu, perempuan terdidik butuh kesempatan untuk berprestasi dan mewujudkan kemampuannya sesuai dengan pengetahuan dan keterampilan mereka. pendidikan dan pengetahuan pekerja perempuan akan mempengaruhi motivasi kerja, produktivitas kerja, yang selanjutnya akan mempengaruhi tinggi rendahnya pendapatan. pada umumnya pekerja yang memiliki pendidikan yang cukup akan lebih terbuka pikirannya, mempunyai kemampuan menerima informasi, dan lebih produktif dalam memanfaatkan sumber-sumber daya yang dimilikinya.

Dari segi sumber daya manusia, Perpustakaan UGM memiliki jumlah pegawai perempuan yang cukup signifikan, seperti ditunjukkan pada tabel 1 . berikut ini.

\section{Tabel 1 \\ Daftar Pegawai Perpustakaan UGM menurut status kepegawaian dan jen is kelamin}

\begin{tabular}{|c|c|c|c|}
\hline $\begin{array}{c}\text { Jenis } \\
\text { Kelamin }\end{array}$ & \multicolumn{2}{|c|}{ Status Kepegawaian } & $\begin{array}{c}\text { Total } \\
\text { Pegawai }\end{array}$ \\
\hline Pustakawan & Administrasi & $\begin{array}{c}58 \\
(41,6 \%)\end{array}$ \\
\hline Perempuan & $42(56 \%)$ & $16(25,8 \%)$ & $\begin{array}{c}79 \\
(58,4 \%)\end{array}$ \\
\hline Laki-laki & $33(44 \%)$ & $46(74,2 \%)$ & 137 \\
\hline Jumlah & 75 & 62 & \\
\hline
\end{tabular}

Sumber : Daftar Urutan Kepangkatan

Perpustakaan UGM tahun 2007

Dari tabel tersebut terlihat bahwa keterlibatan perempuan dalam sektor jasa pelayanan di Perpustakaan UGM cukup besar. Jumlah pustakawan perempuan mendominasi yaitu sejumlah 56\%, sementara itu jumlah pegawai administrasi perempuan hanya $25,5 \%$. Dari jumlah keseluruhan pegawai di perpustakaan UGM sebesar 137 orang, pegawai perempuan mencapai $41,6 \%$. Namun demikian data tersebut belum cukup untuk menunjukkan seberapa jauh perempuan telah berperan dalam sektor jasa pelayanan perpustakaan di Perpustakaan UGM. 
Jumlah perempuan yang cukup besar belum menjamin peran yang dijalankan juga besar. Hal inilah yang mendorong penulis untuk melakukan penelitian yang lebih mendalam tentang peran yang dilakukan oleh perempuan pada sektor jasa pelayanan perpustakaan di Perpustakaan UGM.

Bertitik tolak dari latar belakang di atas, maka rumusan masalah dalam penelitian ini adalah "bagaimana peran perempuan pada sektor jasa pelayanan perpustakaan di Perpustakaan Universitas Gadjah Mada?' Berdasarkan rumusan masalah inilah penelitian ini bertujuan untuk mengetahui bagaimana peran perempuan pada sektor jasa pelayanan perpustakaan di Perpustakaan UGM. Hasil penelitian ini diharapkan dapat memberikan sumbangan pemikiran pada sektor jasa pelayanan perpustakaan, khususnya bagi peningkatan peran perempuan pada sektor jasa pelayanan perpustakaan. Pengetahuan ini akan bermanfaat bagi upaya membangun pendekatan pengelolaan SDM pada sektor jasa pelayanan perpustakaan baik yang berwawasan profesional maupun yang berwawasan gender. Di samping itu manfaat untuk ilmu perpustakaan dan informasi, dengan penulisan ini diharapkan dapat memperkaya khasanah ilmu perpustakaan dan informasi, serta dapat memberi variasi-variasi ilmu yang diperoleh dari suatu tinjauan penelitian organisasi publik.

\section{LANDASAN TEORI \\ 1. Pelayanan Perpustakaan}

Suatu pelayanan akan terbentuk karena adanya proses pemberian layanan tertentu dari pihak penyedia layanan kepada pihak yang dilayani. Layanan dapat terjadi antara seorang dengan seorang, seorang dengan kelompok, kelompok dengan seorang, atau orang-orang dalam organisasi, baik yang dilakukan atas dasar kesukarelaan masing-masing (non-komersial), tujuan komersial antar persona, ataupun orangorang mempunyai keterikatan kerja dalam organisasi yang bertujuan komersial maupun nonkomersial (Barata, 2004: 9-10). Program pelayanan kepada pelanggan dengan bertitik tolak dari konsep kepedulian kepada konsumen terus dikembangkan sedemikian rupa, sehingga sekarang ini program pelayanan telah menjadi salah satu alat utama dalam melaksanakan strategi pemasaran untuk memenangkan persaingan. Kepedulian kepada pelanggan dalam manajemen modern telah dikembangkan menjadi suatu pola layanan terbaik yang disebut dengan layanan prima atau pelayanan prima (Barata, 2004: 25). Pelaksanaan layanan istimewa atau pelayanan prima oleh pihak pemberi layanan terhadap para pelanggan mempunyai peran penting karena kelangsungan usaha tergantung pada loyalitas para pelanggan kepada pihak penyedia layanan. Demikian pula apabila pelayanan prima ini dilakukan dalam organisasi non-komersial maupun pemerintah.

Konsep pelayanan prima itulah yang sedang dikembangkan dan digencarkan di perpustakaan. Kualitas perpustakaan ditentukan oleh berbagai faktor, diantaranya adalah ketersediaan gedung dan fasilitas pendukung, keragaman jenis pelayanan, ketersediaan dan kelengkapan koleksi, serta sumber daya manusia yang memadai baik secara kualitas maupun secara kuantitas. (Lasa Hs., 2005: 49).

Dalam Buku Pedoman Perpustakaan Perguruan Tinggi (2005: 71) disebutkan bahwa layanan perpustakaan ialah pemberian informasi dan fasilitas kepada pengguna. Dalam memberikan pelayanan, perlu diperhatikan asasasas pelayanan sebagai berikut.

1. Berorientasi pada kebutuhan dan kepentingan pengguna.

2. Diberikan kepada pengguna atas dasar keseragaman, keadilan, dan pemerataan.

3. Dilaksanakan secara optimal dan dilandasi oleh peraturan yang jelas.

4. Dilaksanakan secara cepat, tepat, dan mudah melalui cara yang teratur, terarah, dan cermat.

Layanan perpustakaan perguruan tinggi meliputi hal-hal sebagai berikut.

1. Layanan sirkulasi, yaitu layanan peminjaman bahan pustaka untuk dibawa ke luar perpustakaan.

2. Layanan rujukan, yaitu kegiatan untuk membantu pengguna menelusur informasi dalam berbagai subjek. 
3. Layanan multimedia, yaitu kegiatan melayankan bahan multimedia kepada pengguna untuk ditayangkan dengan bantuan perlengkapannya di dalam perpustakaan, misalnya film dengan proyektornya.

4. Jasa kesiagaan informasi (JKI), yaitu salah satu jenis layanan rujukan yang memungkinkan pengguna mendapatkan informasi mengenai bahan perpustakaan baru dalam bidang yang diminatinya.

5. Pendidikan pengguna, yaitu kegiatan membimbing atau memberikan petunjuk kepada pengguna dan calon pengguna agar mampu memanfaatkan kemudahan dan pelayanan perpustakaan dengan efektif dan efisien.

6. Silang layan, yaitu kerjasama antara sejumlah perpustakaan dalam bentuk saling memanfaatkan sumber daya dan layanan informasi semua perpustakaan yang terlibat.

\section{Peran Perempuan}

Peran diartikan sebagai "seperangkat pola perilaku yang diharapkan ada pada seseorang yang menduduki posisi tertentu dalam suatu unit sosial" (Robbin, 2001: ). Sedang menurut Blalock (1987: 19) peranan adalah "konsep yang digunakan untuk mengetahui pola tingkah laku yang teratur dan relatif bebas dari orang-orang tertentu yang kebetulan menduduki berbagai posisi dan menunjukkan tingkah laku yang sesuai dengan tuntutan peranan yang dilakukannya."

Berbicara mengenai peran perempuan dan laki-laki dalam masyarakat, maka tidak akan terlepas dari sebuah dikotomi culture dan nature. Dimana hal tersebut menunjukkan stratifikasi jenis kelamin tersebut melahirkan suatu ideologi yang memisahkan sektor kehidupan ke dalam dua domain, yaitu domestik dan publik. Ideologi tersebut menempatkan perempuan pada sektor domestik dan laki-laki pada sektor publik (Abdullah, 2001: 1006). Ideologi tersebut dikuatkan oleh pranata dan lembaga sosial dalam masyarakat. Hal ini pada akhirnya menjadi realitas sosial mengenai status dan peran yang harus dimainkan oleh perempuan dan laki-laki. Arief Budiman (1985: 2) mengemukakan bahwa masyarakat telah menentukan sendiri peran yang disandang oleh perempuan dan laki-laki.

Dalam membahas peran perempuan yang bekerja pada sektor jasa pelayanan perpustakaan dapat dilihat dari beberapa variabel sebagai berikut.

\section{Tanggapan}

Tanggapan adalah proses komunikasi yang terjadi ketika komunikator mengencode pesan kepada komunikan, dan komunikan mengdecode pesan kepada yang diterimanya (Effendy, 1986: 35). Di sini penulis ingin mengetahui tanggapan yang muncul di kalangan perempuan yang bekerja pada sektor jasa pelayanan perpustakaan terhadap bidang kerjanya. Bentuk tanggapan yang diberikan oleh para responden dibatasi hanya ke dalam persepsi dan motivasi, serta sikap.

2. Partisipasi

Variabel partisipasi digunakan untuk melihat peran sesuai dengan pendapat yang dikemukakan oleh Pareek (1985) bahwa peran adalah sekumpulan fungsi yang dijalankan sebagai tanggapan terhadap harapan-harapan dari para anggota lain yang penting dalam sistem sosial yang bersangkutan. Dengan demikian tanggapan positif terhadap peran yang dijalankan tersebut akan mampu menggerakkan ruang partisipasi para anggota dalam fungsi organisasi.

3. Kompetensi/kapasitas

Variabel kompetensi atau kapasitas dapat diartikan sebagai keterkaitan antara kedudukan, kemampuan, dan keahlian yang dimiliki seseorang dengan fungsi yang dijalankannya dalam organisasi. Faktor keterkaitan ini sangat berpengaruh terhadap berjalan tidaknya fungsi atau peran yang dimilikinya. Semakin tinggi tingkat keterkaitannya berarti seseorang dinilai berkompeten atau sesuai kapasitasnya dalam menjalankan fungsinya tersebut. Buku Pedoman Perpustakaan Perguruan Tinggi merumuskan kompetensi menjadi dua jenis, yaitu :

1) kompetensi profesional, yaitu yang terkait dengan pengetahuan pustakawan di bidang sumber-sumber informasi, teknologi, 
manajemen dan penelitian, dan kemampuan menggunakan pengetahuan tersebut sebagai dasar untuk menyediakan layanan perpustakaan dan informasi; dan

2) kompetensi individu, yang menggambarkan satu kesatuan keterampilan, perilaku dan nilai yang dimiliki pustakawan agar dapat bekerja secara efektif, menjadi komunikator yang baik, selalu meningkatkan pengetahuan, dapat memperlihatkan nilai lebihnya, dapat bertahan terhadap perubahan.

\section{METODE PENELITIAN}

Penelitian ini dilakukan di Perpustakaan UGM dengan menggunakan metode penelitian kualitatif dengan pertimbangan sebagai berikut.

a. Menyesuaikan metode kualitatif lebih mudah apabila berhadapan dengan kenyataankenyataan ganda.

b. Metode ini menyajikan secara langsung hakikat hubungan penelitian dengan informan

c. Metode ini lebih peka dan lebih dapat menyesuaikan diri dengan banyak penajaman pengaruh bersama dan terhadap pola-pola nilai yang dihadapi (Moleong, 1994: 5).

Data primer adalah data yang diperoleh dari responden melalui wawancara langsung dengan menggunakan pedoman wawancara yang dibuat bervariasi antara terstruktur dan tidak terstruktur, dan diperoleh secara langsung di lokasi penelitian. Alat pengumpulan data yang dipergunakan dalam penelitian lapangan ini adalah pedoman wawancara/interview guide yang dipersiapkan terlebih dahulu, dibuat bervariasi antara yang terstruktur dan tidak terstruktur. Dalam penelitian ini, sampel diambil sepanjang subjek dapat memenuhi ketentuan kajian, sehinggan subjek dalam penelitian ini dapat diperoleh melalui teknik puposive sampling, yaitu sampel ditetapkan secara sengaja oleh peneliti (Faisal, 2001: 67). Penentuan sampel dilakukan dengan mengambil orang-orang terpilih betul oleh peneliti menurut ciri-ciri spesifik yang dimiliki oleh sampel tersebut (Nasution, 2001: 98). Subjek dalam penelitian ini adalah pegawai perempuan yang bekerja di Perpustakaan UGM. Jumlah sampel yang diambil berjumlah 7 orang informan yang merupakan perempuan yang terlibat aktif bekerja di sektor jasa pelayanan perpustakaan di Perpustakaan UGM, dan 1 orang kepala perpustakaan sebagai keyperson. Pemilihan sampel diambil untuk mewakili pegawai perempuan pada masingmasing bidang layanan di Perpustakaan UGM.

\section{HASIL DAN PEMBAHASAN}

\section{A. TANGGAPAN}

Salah satu hal yang dapat mempengaruhi peran perempuan dalam jasa pelayanan perpustakaan adalah bagaimana tanggapan perempuan terhadap bidang kerjanya. Adapun tanggapan perempuan dalam hal ini antara lain dapat dilihat dari aspek persepsi, motivasi, dan sikap.

\section{Persepsi}

Persepsi merupakan suatu proses pemilihan bagaimana seseorang dapat tertarik pada suatu obyek sehingga menimbulkan adanya suatu persepsi terhadap obyek yang bersangkutan. Persepsi perempuan terhadap bidang kerjanya bersifat subyektif. Dari hasil wawancara, responden pada umumnya memiliki persepsi yang positif terhadap pekerjaannya. Ada berbagai faktor yang memengaruhi pandangan positif perempuan terhadap tugas pada jasa pelayanan perpustakaan. Hal tersebut antara lain berhubungan dengan faktor psikologis yaitu kepuasan diri. Pekerjaan pelayanan memberikan kenyamanan, terlebih lagi bagi mereka yang sudah berstatus sebagai pegawai negeri sipil. Meskipun masih ada anggapan dari sebagian masyarakat bahwa pekerjaan di perpustakaan membosankan, namun demikian menurut beberapa responden pendapat tersebut tidak sepenuhnya benar. Salah satunya seperti yang diungkapkan responden berikut ini :

"Bekerja di perpustakaan asik tapi berat. Asik karena sibuk, banyak kegiatan, di situ saya bertemu banyak orang. Saya semacam EO yang berhubungan dengan banyak orang, berkenalan dengan banyak orang. Jadi saya tidak melulu melayani orang yang datang, tetapi saya bisa keluar, melakukan promosi dan membuat koneksi dengan orang lain..." (Nur Cahya, 27 November 2007) 
Hampir keseluruhan responden menyatakan bahwa bekerja di perpustakaan sudah sesuai dengan latar belakang keilmuan, tidak banyak menguras tenaga fisik, dapat berinteraksi dengan banyak orang, dapat terus menerus mengikuti perkembangan ilmu perpustakaan, mendapatkan banyak informasi, dan lain sebagainya. Dalam pelaksanaan tugas, pegawai perempuan umumnya melakukan tugas ringan secara fisik. Tugas yang memerlukan tenaga seperti pengembalian dan penataan buku-buku di rak (shelving), tugas fotokopi, dan lain-lain banyak dikerjakan oleh pegawai laki-laki. Setiap pegawai di perpustakaan UGM mendapatkan kesempatan untuk mengakses internet selama dua jam per hari untuk memperluas cakrawala pengetahuannya.

Faktor lain yang membuat citra positif pelayanan perpustakaan adalah kemajuan teknologi. Berbeda dengan beberapa tahun yang lalu ketika semua pekerjaan pelayanan masih dikerjakan secara manual, sekarang semua sudah ditunjang teknologi yang serba praktis. Keberadaan teknologi ini sangat membantu pengguna serta memudahkan dan meringankan petugas pelayanan. Ketersediaan sarana komputer baik komputer khusus kepustakaan maupun komputer untuk tugas administrasi sudah dirasakan mencukupi.

Ilmu perpustakaan dapat dipelajari setiap saat. Bagi yang berlatar belakang pendidikan ilmu perpustakaan, keilmuan yang dimiliki sudah sesuai dengan bidang kerjanya. Sedangkan yang tidak berlatar belakang pendidikan ilmu perpustakaan dapat mempelajari serta mengikuti diklat-diklat atau pendidikan tambahan.

\section{Motivasi}

Faktor berikutnya yang tidak terlepas dari tanggapan adalah motivasi, yaitu suatu kekuatan psikologis yang memberikan dorongan kepada perempuan untuk menekuni pekerjaan pada pelayanan perpustakaan. Seperti pada persepsi, motivasi juga bersifat subyektif. Seperti umumnya perempuan bekerja, motivasi berkaitan dengan masalah eksistensi diri, sosial, dan ekonomi. Sebagian besar responden menyatakan bahwa pada awalnya mereka tidak banyak tahu tentang ilmu perpustakaan. Mereka menempuh bidang pendidikan perpustakaan karena faktor ketidaksengajaan. Perpustakaan merupakan alternatif pilihan terakhir yang diambil, seperti cerita responden berikut :

"Kalau dari awal tidak setertarik sekarang. Awalnya ketertarikanku bukan pada perpustakaan. Walaupun setelah bekerja ingin memperdalam. Pertama kali aku apriori dengan jurusan ini. Walaupun aku dulu juga mencari referensi kalau perpustakaan tidak itu tidak sebatas ini, dan ini dan bukan hanya yang cepete-cepete itu. Cita-cita awal aku ingin menjadi penulis cerita. Terus terang waktu itu mau dibilang antara keblasuk dengan tidak sangat tipis.....Ya karena aku tidak bisa masuk ke S1, kemudian ada program ini ya saya masuk. Banyak faktor kenapa aku memilih jurusan ini. Aku tidak bisa masuk ke sekolah swasta karena nominalnya kurang. Istilahnya waton..." (Uki, 29 November 2006).

Pada kenyataannya banyak hal yang menarik dari dunia perpustakaan. Meskipun terjun di dunia perpustakaan karena faktor "ketidaksengajaan", namun akhirnya mereka dapat "menikmati" pekerjaannya. Dari sisi sosial perempuan bekerja akan memberikan efek positip bagi yang bersangkutan baik di mata keluarga, orang tua dan suami bagi pekerja yang sudah berumah tangga, maupun di mata masyarakat. Sudah jamak terjadi di masyarakat kita, bahwa perempuan yang bekerja akan mendapat nilai yang lebih tinggi dari perempuan rumahan.

Dari sisi ekonomi perempuan bekerja lebih mandiri. Demikian pula perempuan pada sektor jasa pelayanan perpustakaan di Perpustakaan UGM. Mereka mendapatkan gaji beserta segala macan bonus lainnya. Meskipun gaji bukan merupakan tujuan utama bagi beberapa responden, namun hal ini merupakan reward dari tugas-tugas yang sudah dikerjakan. Selain gaji pokok masih ada berbagai tunjangan lain bagi pegawai Perpustakaan UGM sesuai dengan tugas dan fungsinya, antara lain tunjangan 
pustakawan, tunjangan kepangkatan, tunjangan kehadiran yang diberikan setiap tiga bulan sekali, serta insentif lemburan. Rata-rata mereka menyatakan pendapatan yang diterima sudah sesuai dengan pekerjaan yang dilakukan.

\section{Sikap}

Faktor terakhir yang dapat dipergunakan untuk melihat tanggapan perempuan dalam pelayanan perpustakaan adalah sikap. Sikap antara lain dapat dicermati dari sikap dalam memberikan pelayanan kepada pengguna perpustakaan. Sikap yang baik dan ramah merupakan kunci dalam dalam memberikan pelayanan prima, yaitu pelayanan yang memberikan kepuasan kepada pengguna. Hal ini antara lain ditunjukkan dengan memberikan informasi kepada pengguna tanpa diminta, membantu pencarian bahan pustaka yang dibutuhkan, mendahulukan kepentingan pengguna, dan lain-lain. Pernyataan responden berikut dapat digunakan untuk melihat waktu salah satu bentuk sikap yang mendukung konsep pelayanan prima.

“...Kadang-kadang waktu kita mengerjakan hal ini, tiba-tiba ada hal baru yang harus lebih cepat diselesaikan. Yang lain ditinggal dulu, yang baru harus dikerjakan dulu. Misalnya mengolah buku, ketika sedang melakukan ada user minta penelusuran. Ya mengolah buku kita tinggalkan dulu lalu kita bantu user untuk menelusur informasi yang dibutuhkan.....Pekerjaan di sini tidak menuntut tepat waktu. Yang menuntut tepat waktu ya kalau kita sudah janji dengan pengguna, itu harus tepat waktu" (Dewi, 27 November 2006).

Dalam hal pelayanan tampaknya pegawai perempuan lebih menunjukkan sikap telaten dan disiplin dalam melayani pengguna. Pelayanan perempuan dipandang lebih efektif dibanding dengan pegawai laki-laki seperti pernyataan responden berikut.

“...di bagian pelayanan menurut saya samasama tetapi yang efektif biasanya perempuan. Karena kadang-kadang yang laki-laki kelihatan sebentar tetapi nanti enggak tahu ke mana..." (Aprilia, 9 November 2006).

Pada saat ini pengguna perpustakaan yang sebagian besar mahasiswa sudah cukup kritis terhadap sikap pegawai. Mereka tidak segansegan memberikan masukan-masukan baik secara langsung maupun tertulis melalui kotak saran. Keberadaan kotak saran sangat efektif untuk memberikan kontrol terhadap sikap dan pelayanan pegawai. Mayoritas keluhan pada umumnya menunjuk seseorang yang memberikan layanan yang kurang baik. Selanjutnya pihak menejemen akan menindaklanjuti permasalahan tersebut. Seperti yang terjadi beberapa waktu yang lalu ada seorang petugas sirkulasi yang memberikan sikap terlalu keras kepada penguna. Pada akhirnya petugas yang bersangkutan oleh pihak menejemen dipindah pada bagian pelayanan.

\section{B. PARTISIPASI}

Partisipasi merupakan suatu bentuk keikutsertaan dalam setiap kebijakan perpustakaan. Dalam kaitan ini, partisipasi mengandung makna keterlibatan pegawai dalam program pelayanan perpustakaan dalam lingkup kerjanya. Mulai dari proses perencanaan hingga evaluasi pelaksanaan program. Dari hasil wawancara di lapangan, selama ini keterlibatan perempuan dalam proses perencanaan suatu program yang bersifat makro hanya sebatas memberikan masukan-masukan kepada penanggung jawab atau staf yang di atasnya. Sebagian responden tidak mengetahui seberapa jauh usulan mereka berpengaruh terhadap keputusan yang akan diambil. Berikut kutipan pernyataan seorang responden berkaitan dengan hal tersebut.

"Kadang kita dikumpulkan, mau mengusulkan apa ketika menyusun RKAT. Tetapi kita juga tidak tahu nanti hasilnya seperti apa. Yang berperan penting adalah top management (kepala, kabid, dan seterusnya). Apa yang kita usulkan, kalau sudah acc ya kita kerjakan saja. Jadi sifatnya usulan, 
namun mereka yang memutuskan..." (Nur Cahya, 27 November 2006).

Secara umum dapat dikatakan bahwa pengambilan keputusan harus melewati beberapa tahapan. Usulan dari staf ditampung oleh penanggungjawab/Kabid baru diteruskan kepada pihak manajemen. Kadangkala sistem birokrasi semacam ini dirasakan terlalu rumit bagi seseorang, sehingga dianggap sebagai hambatan tersendiri. Seperti yang diungkapkan oleh responden yang bertugas di World Bank Corner.

"Birokrasinya terlalu lama. Misalnya kalau mau bikin event, saya minta tolong beberapa orang. Kalau saya langsung hubungi orang tersebut akan salah. Saya harus ke kabid dulu, ke koordinator dulu, baru kabid perintahkan ke bawahannya. Itu butuh waktu yang sangat lama." (Dewi, 27 November 2006).

Sistem pengambilan keputusan seperti ini berlaku bagi semua staf baik laki-laki maupun perempuan. Jadi dapat dikatakan sebenarnya tidak ada perbedaan bagi keduanya untuk memberikan kontribusi bagi layanan perpustakaan. Demikian pula setiap keputusan yang diambil atau peraturan yang diterapkan tidak memandang jenis kelamin. Dari sisi kedisiplinan, curahan waktu, maupun pemikiran semua pegawai mendapatkan hak dan kewajiban yang sama sesuai dengan tugas yang disandangnya.

Berbeda halnya dengan yang sudah diuraikan di atas, pengambilan keputusan pada level mikro serta pada unit-unit yang lebih kecil umumnya lebih simpel. Hal ini antara lain menyangkut jenis kebijakan yang akan diambil bersifat sederhana serta hanya menyangkut kepentingan unit yang bersangkutan. Sebagai contoh kebijakan masalah denda, biaya bagi pengunjung luar, dan lain-lain. Demikian pula kebijakan-kebijakan pada unit-unit khusus seperti World Bank Corner, American Corner, dan unit khusus lainnya tidak harus melalui tahapantahapan yang cukup panjang tetapi dapat langsung ke Kepala Perpustakaan UGM seperti yang dikemukakan responden dari American Corner berikut ini.
“....Kecuali kalu yang berhubungan dengan kedutaan, saya bisa langsung kontak Kepala Perpustakaan asal tidak menyangkut uang Universitas Gadjah Mada. Saya mengusulkan saja, kalau penentuan tidak....kalau yang berhubungan dengan American Corner itu Kedutaan AS. Kita hanya bisa mengusulkan.Atasan langsung Kabid Pelayanan. Tetapi untuk berbagai kasus saya bisa langsung ke kepala perpustakaan. Karena setahu embassy dia hanya berhubungan dengan dua orang, yaitu kepala perpustakaan dan petugas American Corner". (Nur Cahya, 27 November 2006).

\section{KOMPETENSI}

Kompetensi merupakan salah satu tuntutan yang harus dipenuhi oleh semua perpustakaan. Kompetensi dalam hal ini, seperti yang tertera dalam buku Pedoman Perpustakaan Perguruan Tinggi meliputi kompetensi profesional maupun kompetensi individu. Pada intinya kedua kompetensi ini menunjuk pada pengetahuan dan keterampilan sumberdaya manusia perpustakaan terhadap bidang kerjanya.

Pengetahuan dan keterampilan sumberdaya manusia perpustakaan tidak lepas dari latar belakang pendidikan yang dimiliki oleh yang bersangkutan. Di lingkungan Perpustakaan UGM, sudah banyak perempuan yang mengenyam pendidikan tinggi, dari tingkat D2 hingga S2. Bagi pegawai yang berpendidikan SLTA pada umumnya disekolahkan lagi semacam pendidikan dan latihan (diklat) menjadi SLTA plus (SLTA+). Secara lengkap data mengenai latar belakang pendidikan pegawai di lingkungan Perpustakaan UGM dapat dilihat pada tabel 2 pada halaman sebelumnya.

Dari data tersebut di atas, tampak bahwa pegawai perempuan memiliki pendidikan terendah SLTA yaitu sebanyak 20 orang. Sementara jumlah pegawai perempuan yang menenyam S2 adalah 7 orang. Jumlah ini masih lebih tinggi dibandingkan dengan laki-laki pada jenjang pendidikan yang sama. Sudah barang tentu latar belakang yang dimiliki tersebut akan memberikan pengaruh positip terhadap bidang kerjanya. Selain itu para pegawai juga ditambah 
diklat-diklat seperti tertera dalam tabel 3 di bawah ini.

Tabel 3

Daftar Pelatihan Yang Diadakan Untuk Staf Perpustakaan Lima Tahun Terakhir

\begin{tabular}{|c|c|c|c|}
\hline NO & TAHUN & $\begin{array}{c}\text { NAMA } \\
\text { PELATIHAN }\end{array}$ & $\begin{array}{c}\text { JML. } \\
\text { PESERTA }\end{array}$ \\
\hline 1 & 2002 & - & - \\
\hline 2 & 2003 & $\begin{array}{l}\text { Pelatihan } \\
\text { Komunikasi } \\
\text { Bahasa Inggris } \\
\text { untuk } \\
\text { Perpustakaan }\end{array}$ & 30 orang \\
\hline 3 & \multirow{3}{*}{2004} & $\begin{array}{l}\text { Pelatihan Etika } \\
\text { dan Pelayanan } \\
\text { Perpustakaan }\end{array}$ & 26 orang \\
\hline 4 & & $\begin{array}{l}\text { Pelatihan } \\
\text { Digitalisasi } \\
\text { Dokumen Staf } \\
\text { Perpustakaan } \\
\text { UGM }\end{array}$ & 10 orang \\
\hline 5 & & $\begin{array}{l}\text { Pelatihan Bahasa } \\
\text { Inggris Staf } \\
\text { Perpustakaan } \\
\text { UGM }\end{array}$ & 41 orang \\
\hline 6 & 2005 & $\begin{array}{l}\text { Pelatihan Public } \\
\text { Relations untuk } \\
\text { Perpustakaan bagi } \\
\text { Staf Perpustakaan } \\
\text { UGM }\end{array}$ & 31 orang \\
\hline 7 & 2006 & - & - \\
\hline
\end{tabular}

Proses rekrutmen peserta pelatihan tidak dibedakan antara laki-laki dan perempuan. Unit dari pelatihan adalah unit lembaga bukan individu. Pelatihan apa yang paling dibutuhkan oleh suatu lembaga yang menjadi acuan diadakannya suatu pendidikan dan latihan. Dengan demikian perempuan juga memiliki hak yang sama dengan laki-laki. Seperti pelatihan public relation, yang diikutsertakan kebanyakan perempuan. Belum lama ini dilaksanakan pelatihan akses online journal, pesertanya juga pegawai perempuan semua. Melihat dată pada tabel 3 tersebut jumlah pelatihan sangat sedikit mengingat jumlah pegawai mencapai 137 orang. Beberapa respoden mengungkapkan kebutuhan beberapa jenis pelatihan maupun kursus sangat dibutuhkan untuk menunjang pekerjaan mereka seperti kutipan berikut ini :

“...Saya pikir syarat tertentu tidak perlu, cuma yang harus dimiliki harus ada workshop atau diklat tentang humas karena kita berhubungan dengan banyak orang dengan karakter yang beragam...Selain humas juga perlu pengetahuan tentang etos kerja. Kemampuan bahasa Inggris saya pikir bukan wajib, tetapi setidaknya memang harus bisa dua bahasa Inggris dan bahasa asing lainya karena buku-buku kita tidak melulu berbahasa Indonesia. Pengguna kita juga tidak melulu orang Indonesia..." (Dewi, 27 November 2006)

Sebenarnya memang banyak pelatihan yang akan dilakukan oleh Perpustakaan UGM, namun demikian kadangkala terbentur pada masalah anggaran dari pusat. Dalam proses diklat, pelatihan-pelatihan yang ada selama ini lima puluh persen keputusan berada di pihak Direktorat Sumber Daya Manusia UGM. Oleh karena itu, kadangkala ada rencana pelatihan yang sudah hampir berjalan dan sudah diketahui oleh sebagian karyawan ternyata dibatalkan karena tidak mendapat persetujuan dari pusat, dalam hal ini Direktorat SDM UGM.

Selain melalui diklat dan pelatihan, Perpustakaan UGM juga memberikan kesempatan pegawainya untuk melanjutkan studi ke jenjang yang lebih tinggi melalui program beasiswa. Keputusan akhir penerima beasiswa dan kriteria yang harus dipenuhi berada di pihak Direktorat SDM UGM. Hal ini juga merupakan kendala tersendiri bagi upaya peningkatan kompetensi pegawai perempuan. Standar yang dibutuhkan Perpustakaan UGM terkadang berbeda dengan standar Direktorat SDM UGM. Pada beberapa periode yang lalu sebenarnya ada beberapa pegawai perempuan yang potensial untuk menerima beasiswa, namun karena terbentur standar masa kerja akhirnya mereka tidak lolos.

Dalam rangka peningkatan kompetensi terhadap bidang kerja, pihak Perpustakaan UGM 
sudah lama menerapkan kebijakan rolling. Kebijakan ini dilaksanakan setiap dua tahun sekali. Pada umumnya yang dirolling hanya bagian pelayanan, sedangkan bagian tata usaha jarang terkena kebijakan ini. Pelaksanaan kebijakan bersifat fleksibel. Artinya jika dalam kurun waktu dua tahun belum ada pengganti, maka rolling bisa diundur. Seperti di bagian layanan teknologi informasi atau layanan lain yang memerłukan keahlian khusus.

\section{PEREMPUAN DAN JASA PELAYANAN PERPUSTAKAAN}

Dari beberapa temuan lapangan seperti yang sudah diuraikan di atas tampak bahwa perempuan sudah dapat memberikan kontribusi secara positip dalam ketiga komponen yang menjadi indikator perannya dalam jasa pelayanan perpustakaan. Meskipun belum dapat memberikan perannya secara maksimal, paling tidak perempuan di Perpustakaan UGM sudah terlibat dałam kesełuruhan pełayanan perpustakaan.

Pada prinsipnya setiap petugas perpustakaan diharapkan menguasai keseluruhan proses jasa pelayanan perpustakaan. Meskipun demikian, selama ini pegawai perempuan cenderung mendominasi pelayanan perpustakaan yang berhubungan langsung dengan pengguna. Sebagaimana telah diuraikan dalam tabel 1 bahwa pegawai perempuan di Perpustakaan UGM mencapai $51,6 \%$. Dari jumlah tersebut, menurut hasil pengamatan, tugas-tugas yang banyak dikerjakan oleh pegawai perempuan adalah pelayanan yang langsung berhubungan dengan pengguna, misalnya layanan peminjaman (sirkulasi), layanan referensi, layanan koleksi American Corner, World Bank Corner, dan sebagainya. Menurut para responden, hat inj wajar terjadi karena perempuan dianggap luwes, ramah, telaten, teliti, dan tidak membutuhkan banyak tenaga fisik. Sebagaimana kutipan dalam wawancara dengan seorang responden di bawah ini.

“..ya dibilang cocok ya cocok karena di bidang perpustakaan lebih banyak ketelitiannya, ketelatenannya. Misalnya seperti jasa penelusuran yang lebih telaten perempuan. Kalau yang laki-laki misalnya informasi yang dicari tidak ditemukan, ya sudah ah...tidak ada. Kałau perempuan lebih telaten dalam melayani mahasiswa yang banyak tanya, minta ditunjukkan ini...itu...dan sebagainya." (Ratna, 8 November 2006).

Hal ini sejalan dengan apa yang dikemukakan oleh Sadyono dalam penelitiannya pada beberapa perusahaan bahwa seringkali perempuan hanya cocok bagi pekerjaan feminim atau pekerjaan yang berkaitan dengan nalurinya dalam peran sebagai ibu rumah tangga atau mitra laki-laki misalnya guru, perawat, pelayan restoran, operator telepon, teller bank, dan lainlain (Sedyono dalam Partini, 1996). Padahal sebenarnya tidak tertutup kemungkinan bagi pegawai perempuan untuk terlibat dalam jasa pelayanan yang selama ini seolah-olah sudah menjadi dunia laki-laki seperti pelayanan yang berkaitan dengan teknologi informasi. Sudah ada beberapa pegawai perempuan yang ditempatkan di bagian ini, namun baru terbatas pada pekerjaan-pekerjaan teknis seperti input data buku ke dalant database perpustakaan, penelusuran informasi dengan menggunakan OPAC (online public access catalog). Sedangkan pekerjaan-pekerjaan terkait dengan teknologi informasi yang lebih jauh seperti pemrograman, analisis data, dan penanganan sistem informasi perpustakaan, belum melibatkan perempuan.

Kebijakan rotasi pegawai seperti yang telah disebutkan sebelumnya pada dasarnya juga merupakan salah satu dukungan penguasaan pelayanan di Perpustakaan UGM. Petugas yang menguasai masing-masing bidang pelayanan sudah barang tentu akan mampu memberikan pelayanan yang prima, yaitu pelayanan yang memberikan kepuasan kepada pengguna, memberikan fasilitas serta informasi yang dibutuhkan oleh pengguna.

Perpustakaan UGM tidak melihat peran pegawainya dalam memberikan pelayanan prima apakah yang bersangkutan laki-laki atau perempuan. Faktor etic dan skill yang menjadi landasan untuk melihat kapasitas seorang pegawai. Bagaimana seseorang berkomunikasi, 
berinteraksi $\therefore$ dan mengkomunikasikan pengetahuannya kepada pengguna layanan perpustakaan merupakah hal utama yang harus dimiliki oleh setiap pegawai berkaitan dengan perannya. Selain itu aktivitas dan kreativitas juga merupakan kunci utama peran dalam pelayanan perpustakaan. Oleh karena itu, untuk lebih dapat berperan, perempuan harus memiliki ide-ide baru, rencana kegiatan, dan lain-lain untuk menunjang keberhasilan pelayanan, seperti petikan wawancara dengan Kepala Perpustakaan UGM berikut ini.

"Kadang kegiatan tidak harus berasal dari pimpinan, pimpinan tidak selalu ini tolong lakukan ini. Ya kalau itu tidak jalan, baru kita lakukan itu. Tetapi ide seringnya datang dari mereka, justru lalu kita tanya apa kira-kira yang cocok untuk ini. Misalnya di Bagian World Bank Corner, American Corner itu kita tanya, dan kebetulan mereka perempuan semua. Aktivitasnya apa untuk ke depan. mereka yang merencanakan. Siapapun termasuk di situ perempuan, dan di bawahya bisa laki-laki ya di situ, seperti di American Corner itu di bawahnya laki-laki dan golongannya justru lebih tinggi. Jadi schedule atau yang membuat kegiatan itu kadangkadang datang dari wanita. Yang lebih pas itu kreativitas yang dituntut." (Ida Fajar P, 13 Desember 2006).

Dalam prakteknya meskipun perempuan dapat dikatakan sudah berperan dalam berbagai layanan perpustakaan, namun demikian ada berbagai kendala bagi perempuan untuk dapat berperan penuh dalam jasa pelayanan perpustakaan tersebut. Kendala ini seringkali membuat perempuan tidak dapat sejajar dengan laki-laki dalam menjalankan perannya. Kendala yang selama ini sering dihadapi oleh pegawai perempuan terbagi menjadi dua, yaitu kendala internal dan kendal ekstemal. Kendala internal berasal dari diri perempuan sendiri. Sedangkan kendala eksternal berasal dari keluarga, lingkungan kerja, kebijakan, dan lain sebagainya.

Kendala internal berkaitan dengan kodrat perempuan serta siklus hidup yang dialami. Kodrat berhubungan dengan haid, hamil, melahirkan dan menyusui, serta hubungan batin antara anak dan ibu (Partini, 1999: 317). Dari hasil wawancara di lapangan, sebagian responden menyebutkan kondisi fisik, seperti pada saat haid atau sakit dapat mengganggu tugas pelayanan. Terlebih lagi bagi mereka yang berada dalam tim kerja dalam jumlah yang terbatas sehingga sulit untuk bergantian. Selain kondisi fisik, jam kerja yang cukup panjang hingga sore hari juga dirasakan cukup berat dan mengganggu aktivitas kerja di rumah sebagai ibu rumah tangga, Seperti yang disampaikan oleh seorang responden berikut ini.

" Jam kerja sampai sore, padahal di rumah harus masak, mencuci, dan sebagainya. Manajemeıl waktu tidak ada masalah, tetapi kalau di kantor capek maka di rumah ya hanya tiduran saja ..." (Aprilia, 9 November 2006)

Tidak mudah bagi perempuan untuk melaksanakan tuntutan serta menjaga keseimbangan antara perannya sebagai pegawai perpustakaan dengan peran sebagai ibu rumah tangga. Dalam hal ini perlu keseimbangan tugas antara laki-laki dan perempuan baik di rumah maupun di lingkungan kerja sehingga tercipta hubungan yang sederajat.

Kendala eksternal pada umumnya berasal dari keluarga dan dari luar keluarga. Kendala dari keluarga sangat dirasakan oleh pegawai perempuan terutama yang telah berkeluarga dan memiliki anak. Pada umumnya perempuan sepakat untuk mengakui bahwa kepentingan suami dan anak ditempatkan sebagai kepentingan utama. Berbakti dan berkorban untuk keluarga merupakan paket yang datang bersama dengan diterimanya status sebagai istri (Sitepu dalam Partini, 1999: 335). Masuknya perempuan dalam pekerjaan formal seperti bekerja di perpustakaan merupakan permasalahan tersendiri. Meskipun beberapa responden sudah memiliki peran pengganti untuk melakukan pekerjaan-pekerjaan rumah tangga, namun tidak dengan sedemikian rupa lepas dari permasalahan. Sebagai contoh ketika anak sedang sakit dan memerlukan perawatan khusus. Pegawai perempuan umumnya 
harus ijin kerja, sehingga dapat menghambat pekerjaan kantor. Selain itu, dalam hal peningkatan karir, kadang-kadang perempuan tidak dapat memutuskan sendiri, melainkan dengan persetujuan suami atau orang tua. Ketika ijin tidak diberikan, hal ini merupakan hambatan bagi laju peran perempuan yang bersangkutan. Hal itu diungkapkan oleh pihak manajemen Perpustakaan UGM dalam petikan wawancara berikut ini.

"Saya justru melihat kadang-kadang perempuan terhambat sendiri di dalam keluarga. Sementara kita mendukung, tetapi tidak diperbolehkan oleh suami misalnya ..." (Ida Fajar P, 13 Desember 2006).

Kondisi seperti ini akan menyulitkan bagi perempuan yang bersangkutan ketika harus mengikuti pelatihan-pelatihan atau tugas lain yang berkaitan dengan kompetensinya. Terlebih lagi ketika kebijakan dan manajemen bersifat "lunak" akan semakin memudahkan perempuan pada satu sisi tetapi merugikan pada sisi lainnya.

Hambatan eksternal lain berasal dari lingkungan kerja. Tidak selamanya lingkungan kerja memberikan dukungan yang positip terhadap prestasi kerja seseorang. Persaingan antar teman kerja juga dapat menjadi faktor penghalang kemajuan perempuan. Lingkungan kerja yang tidak kondusif serta tidak memberikan apresiasi positip terhadap prestasi kerja dan kedisiplinan juga memberikan dampak buruk terhadap perempuan, seperti yang diungkapkan responden di bawah ini.

"Sebenarnya semua orang seneng dipuji, dikasih pekerjaan. Cuma di sini budayanya itu kalau kita dapat pujian malah diejek, sehingga tidak memotivasi lainnya untuk bekerja lebih baik. Umpamanya kayak kita di majalah saya sempat bilang mbok ini diindeks. Eee...tapi jawabnya malah ...ah..enggak ah, nanti ndak malah dikira mencari pujian ..."(Dewi, 27 November 2006).
Sebenarnya dalam satu lingkungan kerja harus memberikan dukungan positip antar teman seprofesi sehingga tercipta peranan yang imbang.

\section{PENUTUP}

Peran perempuan dalam jasa pelayanan perpustakaan di Perpustakaan UGM dipengaruhi oleh beberapa hal, antara lain oleh tanggapan perempuan yang terdiri dari persepsi dan motivasi, serta peran; partisipasi; dan kompetensi. Citra positip yang terbentuk pegawai perempuan terhadap bidang kerjanya akan memberikan kontribusi semakin besar terhadap peran perempuan dalam jasa pelayanan perpustakaan. Selama ini kebijakan dan peraturan yang berlaku di Perpustakaan UGM memberikan peluang yang sama bagi perempuan untuk memberikan peranan pada jasa pelayanan perpustakaan. Pegawai perempuan lebih dominan menempati posisi pada bidang pelayanan yang langsung berhadapan dengan pengguna, seperti pada pelayanan sirkulasi, pelayanan referensi, pelayanan penelusuran informasi, dan sebagainya. Hal ini antara lain berhubungan dengan sifat perempuan yang ramah, terampil, dan rajin. Disamping itu, adanya berbagai kendala baik dari dalam diri (internal) maupun dari luar (eksternal) memberikan pengaruh yang nyata terhadap peran perempuan.

Atas dasar kesimpulan dan uraian sebelumnya, ada beberapa yang perlu dipikirkan untuk dapat meningkatkan peran perempuan dalam jasa pelayanan perpustakaan sebagai berikut.

a. Untuk peningkatan perannya, perempuan perlu lebih ditingkatkan kualitasnya sebagai penyedia jasa pelayanan, antara lain diberikan keterampilan-keterampilan dan pelatihan yang mengarah pada baragamnya jenis pekerjaan layanan yang dapat dilakukan.

b. Melibatkan secara aktif perempuan dalam berbagai kebijakan pelayanan perpustakaan. Karena perempuan sebagai salah satu pelaku akan lebih mengerti apa yang menjadi kebutuhan dalam pelayanan perpustakaan.

c. Melibatkan perempuan pada bidang-bidang yang selama ini banyak didominasi laki-laki, seperti layanan multimedia dan teknologi 
informasi lain, mengingat teknologi perpustakaan cepat mengalami perubahan. Dengan demikian perempuan tidak mengalami ketinggalan dalam hal teknologi di perpustakaan.

d. Perlu peningkatan kualitas pendidikan perempuan dengan mengikutsertakan dalam program studi lanjut ke jenjang berikutnya melalui program beasiswa. Pelaksanaan pemberian beasiswa tersebut sebaiknya dilaksanakan secara transparan, disosialisasikan kepada seluruh karyawan, dan syarat-syarat yang ditetapkan secara jelas. Seluruh pegawai yang memenuhi persyaratan memiliki hak yang sama untuk mengikuti seleksi secara terbuka.

e. Perlunya peningkatan sinergi antar bagian pelayanan sehingga ketika ada beberapa staf yang berhalangan, staf lain dapat menggantikannya sehingga dapat mengurangi beban kerja. Dengan demikian tidak mengganggu peran perempuan dalam pelaksanaan tugasnya.

\section{DAFTAR PUSTAKA}

Abdullah, Irwan (ed.). 1997. Sangkan Paran Gender. Yogyakarta: Pustaka Pelajar.

Boserup, Ester. 1984. Peranan Wanita dalam Perkembangan Ekonomi. Jakarta: Yayasan Obor Indonesia.

Budiman, Arief. 1982. Pembagian Kerja Secara Seksual. Jakarta: Gramedia.

Buku Pedoman Perpustakaan Perguruan Tinggi. 2005. Jakarta: Perpustakaan Nasional Republik Indonesia.

Barata, Atep Adya. 2004. Dasar-dasar Pelayanan Prima: Persiapan Membangun Budaya Pelayanan Prima untuk Meningkatkan Kepuasan dan Loyalitas Pelanggan Tanggung Jawab Perpustakaan dalam Mengembangkan Masyarakat Informasi. Jakarta: Elex Media Komputindo.

Blalock, Hubert M. Jr. 1987. Pengantar Penelitian Sosial. Jakarta: Rajawali Press.

Effendy, Onong Uchjana. 1986. Pengantar Ilmu Komunikasi: Teori dan Praktek. Jakarta: Remaja Rosdakarya.

Faisal, Sanapiah. 2001. Format-format Penelitian Sosial. Jakarta: Rajawali Press.
Hadi, Soetrisno. 1997. Metodologi Research untuk Penulisan Paper, Skripsi, Thesis dan Disertasi. Yogyakarta: Yayasan Penerbitan Fakultas Psikologi UGM.

Hasibuan, Malayu S.P. 1990. Manajemen Sumber Daya Manusia: Dasar dan Kunci Keberhasilan. Jakarta: Haji Masagung.

Kagan, Jerome dan Emest Havemann. 1980. Psychology: an Introduction. New York: Harcourt Brace Irvanovich.

Keputusan Presiden Nomor 11 Tahun 1989 tentang Perpustakaan Nasional

Koentjaraningrat. 1982. Masyarakat Desa di Indonesia. Jakarta: FE UII.

Lasa Hs. 2005. Manajemen Perpustakaan. Yogyakarta: Gama Media.

Miles, Matthew B. dan Huberman. 1992. Analisis Data Kualitatif: Buku Sumber tentang Metode-metode Baru. Jakarta: Penerbit Universitas Indonesia (UI-Press).

Moenir, HAS. 1992. Manajemen Pelayanan Umum di Indonesia. Jakarta: Bumi Aksara.

Moleong, Lexy J. 2007. Metodologi Penelitian Kualitatif. Bandung: Remaja Rosdakarya.

Mubyarto. 1984. Peluang Kerja dan Berusaha di Pedesaan. Yogyakarta: BPFE.

Nasution. 2001. Metode Penelitian Kualitatif Naturalistik. Bandung: Tarsito.

Nawawi, Hadari. 1996. Manajemen Pelayanan Umum di Indonesia. Jakarta: Bumi Aksara.

Newcomb, Theodore M. [et al.]. 1978. Psikologi Sosial. Bandung: Diponegoro.

Pareek, Udai. 1985. Mendayagunakan Peran-peran Keorganisasian. Jakarta: Pustaka Binaman Pressindo.

Peraturan Pemerintah Republik Indonesia Nomor 153 Tahun 2000 tentang Penetapan Universitas Gadjah Mada sebagai Badan Hukum Milik Negara

Qalyubi, Syihabuddin, dkk. 2003. Dasar-dasar Ilmu Perpustakaan dan Informasi. Yogyakarta: Jurusan Ilmu Perpustakaan dan Informasi Fakultas Adab IAIN Sunan Kalijaga.

Rahmat, Jalaludin. 2001. Teori-teori Komunikasi. Bandung: Bina Cipta.

Ratminto. 2005. Manajemen Pelayanan: Pengembangan Model Konseptual, Penerapan Citizen's Charter dan Standar Pelayanan Minimal. Yogyakarta: Pustaka Pelajar.

Soekanto, Soerjono. 1981. Sosiologi Suatu Pengantar. Jakarta: UI Press. 
Sudiana, Dendi. 1986. Komunikasi Periklanan Cetak. Bandung: Remaja Rosdakarya.

Sutarno N.S. 2005. Tanggung Jawab Perpustakaan dalam Mengembangkan Masyarakat Informasi. Jakarta: Panta Rei.

Garis-Garis Besar Haluan Negara (GBHN) 1993 pada Bidang Kesejahteraan Rakyat, Pendidikan dan Kebudayaan

Partini. 1999. Peluang Pegawai Wanita Untuk Menduduki Jabatan Struktural. Universitas Gadjah Mada, Yogyakarta.

Sutarno N.S. 2005. Tanggung Jawab Perpustakaan dalam Mengembangkan Masyarakat Informasi. Jakarta: Panta Rei.

Sulistyo-Basuki. 2001. Pengantar Ilmu Perpustakaan. Jakarta: Gramedia Pustaka Utama.

Thoha, Miftah. 1991. Beberapa Aspek Kebijaksanaan Birokrasi. Yogyakarta: Media Widya Mandala.

Thoha, Miftah. 1998. Perilaku Organisasi. Jakarta: Rajawali Press.

De Lozier, M. Wayne. 1976. The Marketing communication Process. Tokyo: McGrowHill Kogakusha Ltd.

Schramm, Wilbur dan Donald D. Robert. 1971. The Process and Effect of Mass Communication. Illinois: University of Illinois.

Sudiana, Dendi. 1986. Komunikasi Periklanan Cetak. Bandung: Remaja Rosdakarya.

Undang-Undang Dasar 1945.

Undang-Undang Nomor 20 Tahun 2003 tentang Sistem Pendidikan Nasional

Undang-Undang Nomor 2 Tahun 1989 tentang Sistem Pendidikan Nasional. 